\title{
SSinteza
}

Impact of Internet on Business Activities

\section{THE USE OF THE INTERNET AND DEVELOPMENT PERSPECTIVES OF LABOUR MARKET IN SERBIA}

\author{
Marina Savković, Nataša Stanišić \\ Singidunum University, Serbia
}

\begin{abstract}
:
Wide range of modern IT application in economics has a significant impact on labour market. This analysis is directed towards the key transformational processes on/in labour market, which are the result of the Internet development. Some of the featured trends are: changes present in needed education requirements and workforce structure, required working hours, wages and methods of finding new employees and jobs. The analysis would also include changes made in the form of institution influences in labour market. Finally, the evidence is applied to Serbian labour market and labour market outcomes potential for improvement.
\end{abstract}

\section{Key words:}

labour market, the Internet, development trends, Serbian market perspectives.

\section{INTRODUCTION}

Complementing and stimulating globalization processes, the Internet probably presents the most important medium of communication worldwide. In that way, it stimulates international markets' integration, business relocation and the emerging trend of business outsourcing.

The questions that should be answered are how and to which extent the Internet affects labour market. It is particularly related to labour market structure, efficiency and equality of labour market outcomes, workforce competences, work conditions and labour market institutions. This paper is structured to give evidence related to the general question and subquestions, main concerns and to show development perspective of labour market in the Internet era.

\section{LABOUR MARKET STRUCTURE}

The usage of the Internet enhances local and national markets' interdependence, connecting those in a global prospect. Considering trade theory, integrating labour markets have substantial benefits [3]. Work is redistributed to places where wages are lower, which reduces labour costs and puts comparative advantages of particular regions in focus. It should stimulate: productivity and wages' growth, quality and the variety of products available and living standard. Productivity should also be increased by intensified outsourcing, local business and labour specialization [2].

Connection between natural rate of unemployment and the usage of the Internet is very difficult to quantify. It is suggested that the Internet may have reduced frictional and shortening the job search period, but the magnitude is still unknown [6]. According to [3], having access to broad-band services in a county is associated with about 1.8 percentage points increased employment rate, emphasizing larger effects in rural and isolated areas. That local market evidence is not consistently confirmed on national labour market level.

Evidence is mostly consistent to highly educated labour force, showing positive correlation of the usage of the Internet and employment., Highly educated married women who use the internet are more likely to participate in labour force and make work-family balance [3]. The Internet is available and widely used by young people, who present one of the most vulnerable groups in labour market. The Internet development has potential to increase their employability and shorten the time of school-to-job transition. People with disabilities are also a group that could benefit from the usage of the Internet, but the evidence is rare in this case..

\section{WORKFORCE COMPETENCES, WORKING HOURS AND WAGES}

The Internet changes skills needed in everyday business, but also the ways of the skills' acquiring [2]. Educational programmes and skills trainings', organized in a virtual environment, via the Internet, have the potential to reduce the cost and increase the convenience of ongoing skills development. Educational contents are widely available online, many of those free of charge and everyone can access them. Individuals are able to filter the sources they want to use in their learning process, and create personal learning environments (PLE). Competences become less exclusive, thus intuitively increasing competition in supply segment of labour market. , there is no clear evidence 
of the online training programmes efficiency, thus showing potential for further research in this field [2].

Considering employment structure, IT occupations show the rapidly increasing trend. It is mostly visible in OECD countries that developed substantial Internet access and high-tech sectors [1]. Bearing in mind country specializations and the trend of global outsourcing, the Internet provides an opportunity to countries like India and Brazil to develop intensively IT workforce, that could be employed by local and international companies, finally providing services for the third parties in developed countries [4].

According to [2], workers who use the Internet at home extensively have increased working hours at home, without decreasing their time in the office. It could be explained with leisure/work substitution effect, initiated by increased productivity when working at home. Anyway, intuitive assumption that implies the fact that the Internet should shorten working hours cannot be proven. The Internet is likely to change the way in which some workers deliver their services. It is related to the increasing trend of working from home, but also to the outsourcing services from the other parts of the world. Anyway, there is evidence that the Internet and face-to-face contact are not substitutes, but rather complements, making synergy and resulting in workers' efficiency. [2].

Computer use is positively associated with hourly earnings [1]. There is mixed evidence related to the usage of the Internet and wage premium. Some analyses show positive link between the usage of the Internet and hourly earnings [1], while some other references show neutral or opposite results. At the beginning of 2000s, there was nearly $80 \%$ increase in the usage of the Internet at work, which was not followed by wage changes [8]. The possible explanation is attached to the fact that specific skills must be acquired, with regard to the computer usage, and fewer competences needed, with regard to the Internet users.

\section{JOB APPLICATION PROCESS}

The Internet changes the way that employer-employee matches are made [2], which is followed by numerous consequences and effects on labour market. Job application presents one of the related fields, with the most revolutionized transformation in this sense. Using the internet, both supply and demand side of labour market create benefits. Those are primarily related to costs and time involved in potential "matches". That can indicate labour market efficiency improvement, as a direct effect of the Internet use.

On one hand, job applicants can use many online portals specialized in job search. These websites integrate informational function with searching and matching engines, developed according to user preferences. They allow individuals to advertise their skills to employers, as well as the reverse. [2] In that way, bearing in mind the wide availability of the Internet connection, information asymmetry in labour market decreases, which improves labour market efficiency, but also the equity of labour market outcomes. Anyway, some evidences show that the
Internet job search is ineffective in reducing unemployment duration, which could be connected to specific demographic characteristics of the Internet job searchers [7].

Some of the critiques in this sense are related to fact that all the said can be applied only to relatively well-educated people (usually highly educated), who actively use the Internet on a daily basis and actually do not require the assistance of the Internet to find a job [7]. This argument also suggests that labour market is not becoming more inclusive in the Internet era. In the last few years, there have been several examples of job portals in India, specialized in jobs for low qualified workers, which show/ have shown a positive trend in inclusion sense, but it is still not the overall trend [1].

Using the Internet, companies provide a wide base of job applicants, with relatively low cost. Also, applicant profiles on professional and informal social networks (LinkedIn, Facebook etc), include numerous information on candidates' profiles and interests. The challenge in this case is related to the increased efforts needed for quality selection. Since the Internet provides an efficient way of looking for job and candidates, labour market search theory indicates that it could lead to better matches and improved labour productivity [2]. On the other side, the Internet does not give reliable way of job applications and candidates profiles' accuracy, which implicitly increases the costs of establishing new employee qualifications [2]. In response to the issue of excess and inappropriate applications, job portals usually offer pre-filtering, to prevent unqualified applicants from submitting resumes [2].

\section{LABOUR MARKET INSTITUTIONS}

Trade unions are also transforming/have also transformed their activities in the Internet era. The Internet can be used as a tool for servicing members and distributing their message to the public. It raises the possibility for large scale changes, in the nature of the union movement [1]. Trade unions, which are able to effectively use the Internet, can reach much wider population than it was the case before.

Also, the Internet provides an opportunity for the development of new institutions, that can address labour issues, in the way trade unions did before [2]. Trade unions are not that "exclusive" anymore, so their negotiation power, individually, should decrease. The direct consequence of the previously said is the increased competition in the field of institutional influence on labour market, which, logically, should lead to the improved equality of labour market outcomes, in the first place, and also decreased labour market duality, as an indirect effect of it. Some of the new labour market intermediaries are directly competing for formal institutional negotiation role, usually connecting themselves with independent contractors or some other actors who were not efficiently serviced by traditional trade unions [2].

New labour market intermediaries have their chance to conduct their role through talent management, offering reputation to its members and representing workers quality [2]. There are arguments showing that those roles 
cannot be carried out by free agents, so there is an opportunity for the new web-based organizations to become a legitimate element of the institutional system standing behind labour market. On the other side, traditional labour unions can try to improve their activities, developing some of the mentioned roles [1].

If unions are not able to transform their mission, in accordance with the new institutional labour market trends, new intermediaries, including free agents will take over proportion of their activities. A concern given in this sense is related to pre-Internet union leaders, who could not have fully understood the opportunities of the usage of Internet [1].

\section{THE INTERNET AND DEVELOPMENT PERSPECTIVES OF SERBIAN LABOUR MARKET}

Serbian labour market characteristics can be summarized in the following way:

- Multidimensional labour market duality

- High unemployment rate

- Small percentage of highly educated workers, compared to the European average rate

- Qualitative discrepancy of supply and demand segment of labour market

- Relatively underdeveloped labour market institutions

Labour market in Serbia has characteristics both of the markets in developed European countries and transitional economies [9]. Since the Internet increases markets interdependence globally, it can be said that workers in Serbia become more similar to workers in other countries as never before. The same could be concluded for the employers' requirements regarding workforce competences and job characteristics. Disregarding overall macroeconomic empirical trends in the country, the Internet should stimulate market competition but also create potential for Serbian labour market outcomes to be improved

Taking into account previously analyzed Internet influence on labour market functioning, the potential of Serbian labour market development in the Internet era can be seen in the following perspectives:

- decreased labour market duality, as a consequence of decreased information asymmetry and market competition

- decreased unemployment rate, particularly related to the well educated workers, women and young people

- promoted labour market efficiency, through the Internet job searching and networking functions

- improved workforce educational structure, using the Internet as a set of learning tools

- empowered labour market institutions, strengthening and widening their roles and communication channels

\section{CONCLUSION}

As much as any other market, labour market expands in cyber-space. It cannot be said for sure whether this is positive or negative, in the context of labour market structure and outcomes. The usage of the Internet improves labour market efficiency in several ways, which is mostly analyzed in job matching context.

Positive effects of the usage of the Internet on equality of labour market outcomes have not been proven, since the evidence shows that majority of benefits are distributed towards highly educated workers. Talent mining practice confirms this conclusion. Although the Internet improves position of some workforce segments, the general suggestion could be that it does not improve equality of labour market outcomes to a greater extent.

The Internet usage results in longer working hours, but mostly with decreasing or no wage premiums. Specific workforce skills are not stressed, which is different in the case of computer use skills. There is a remarkable trend of the increasing number of workers involved in IT sector, including the Internet- related jobs, which proportion, in the ratio of general employment, grows.

Finally, labour market institutions are faced with competition of new the Internet-based intermediaries, so those are forced to reform and spread the scope of their activities. They are going more public and online, thus reaching new roles and new membership Being able to reach specific individuals, the Internet should continue influencing labour market by being more inclusive and should also further continue enhancing job creation and job flexibility.

All the conclusions refer to Serbian labour market and possible ways of its improvement. Specifically, the identified potentials are related to: labour market efficiency, workforce educational structure, employment level of particular workforce segments and labour market institutions recovery.

\section{REFERENCES}

[1] R. Freeman, The Labour Market in the New Information Economy, NBER WorkingPaperSeries, WorkingPaper No 9254, National Bureau of Economic Research, Cambridge, available at: http://www.nber.org/papers/w9254,

[2] D. Autor, Wiring the Labour Market, Journal of Economic Perspectives-Volume 15, Number 1-Winter 2001-Pages 25-40I.S.

[3] H. Atasoy, The Effects of Broadband Internet Expansion on Labour Market Outcomes, Job Market Paper, University of Illinois at Urbana Champaign, November 13. 2011

[4] World Bank, World Development Report 2013 - Jobs, Washington, 2012

[5] L. J. Dettling, Broadband in the Labour market: The Impact of Residential High Speed Internet on Married Women's Labour Force Participation, Federal Reserve Board, September 2013

[6] Congress of the United States, The Effect of Changes in Labour Markets on the Natural Rate of Unemployment, A CBO Paper, Congressional Budget Office, 2002

[7] M. J. William, The Dynamics of Internet Recruiting: An Economic Analysis, University of Michigan, Issues in Political Economy, Vol. 16, August 2007

[8] S.Lee, J. Kim, Has the Internet changed the wage structure too?, Labour Economics 11 (2004) 119- 127

[9] M. Arandarenko, Tržište rada u Srbiji - Trendovi, institucije, politike, Centar za izdavačku delatnost ekonomskog fakulteta u Beogradu, Beograd, 2012 